\title{
ANALISIS KEGAGALAN TIANG PANCANG PADA KONSTRUKSI DERMAGA DENGAN PROGRAM APILE OFFSHORE, LPILE, DAN GRLWEAP
}

\author{
Ivana Natasha ${ }^{1}$ dan Chaidir A. Makarim \\ ${ }^{1}$ Program Studi Sarjana Teknik Sipil, Universitas Tarumanagara, Jl. Letjen S. Parman No.1 Jakarta \\ Email: ivananatasha211096@gmail.com \\ ${ }^{2}$ Program Studi Sarjana Teknik Sipil, Universitas Tarumanagara, Jl. Letjen S. Parman No.1 Jakarta \\ Email: chaidir259@gmail.com
}

\begin{abstract}
ABSTRAK
Konstruksi lepas pantai (offshore) berbeda di dalam perencanaannya dengan konstruksi di daratan (onshore) dan kosntruksi di dekat pantai (near shore). Analisis yang dilakukan pada skripsi ini menggambarkan interaksi antara konstruksi dengan parameter hidrodinamika, antara lain: beban siklik akibat ombak berulang, penggerusan (scouring), dan gaya gesek selimut negatif akibat endapan dari muara sungai. Skripsi ini memaparkan perbedaan tersebut dan menampilkan contoh kegagalan yang terjadi pada suatu proyek dermaga pada salah satu kawasan pulau di Indonesia. Metode yang dapat digunakan untuk menganalisis kegagalan antara lain adalah dengan menggunakan analisis kapasitas tiang dan data hasil pukulan tiang untuk mendapatkan kapasitas tiang secara aksial dan lateral dengan program APILE Offshore dan LPILE, serta simulasi pemancangan tiang dengan program GRLWEAP. Input parameter yang digunakan berupa parameter tanah, tiang, dan hammer. Hasil analisis dari program akan dibandingkan dengan kapasitas tiang hasil uji pembebanan dinamik (PDA test) dan kalendering serta beban yang harus dipikul oleh tiang.
\end{abstract}

Kata kunci: Offshore, Pondasi tiang, APILE Offshore, LPILE, GRLWEAP.

\section{PENDAHULUAN}

Konstruksi lepas pantai (offshore) berbeda di dalam perencanaannya dengan konstruksi di daratan (onshore) dan konstruksi di dekat pantai (near shore) dan merupakan sebuah anjungan besar yang menyediakan fasilitas seperti pelabuhan. Pembangunan pelabuhan memegang peranan penting seperti administratif, perkembangan, industrial, dan komersil. Pelabuhan mencakup struktur dermaga yang merupakan fasilitas tempat kapal keluar masuk dan transfer muatan yang umumnya terletak pada tepi laut, sungai, maupun danau.

Struktur pada dermaga didukung oleh pondasi yang meneruskan beban yang dipikul ke dalam lapisan tanah. Tanah harus mampu memikul beban tanpa mengalami kegagalan. Pondasi yang umumnya digunakan adalah pondasi tiang. Pada tahap perencanaan, daya dukung pondasi perlu diperhatikan secara saksama karena kegagalan konstruksi dapat terjadi apabila pondasi tidak mampu menahan beban yang dipikul. Kegagalan yang terjadi pada tiang pancang konstruksi dermaga pada salah satu kawasan pulau di Indonesia merupakan suatu kasus nyata yang menimbulkan permasalahan pada struktur dermaga dan trestle.

Pengujian pada pondasi tiang perlu dilakukan untuk memperoleh verifikasi terhadap hasil desain pondasi berdasarkan data tanah yang tersedia, memberikan kepastian kepada insinyur desain dalam menentukan metode instalasi pondasi tiang, kapasitas tiang, memprediksi besarnya defleksi yang terjadi, dan mengetahui integritas pondasi tiang. Pengujian kapasitas tiang pondasi di darat (onshore) dapat dilakukan secara statik, namun hal ini sangat sulit dilakukan pada konstruksi lepas pantai (offshore) karena lingkungan dan beban muatan yang besar. Oleh sebab itu pengujian secara dinamik merupakan alternatif yang dapat ditempuh untuk menentukan kapasitas pondasi tiang, seperti Pile Driving Analyzer (PDA) test untuk memperoleh informasi mengenai kapasitas, integritas, dan memonitor instalasi pondasi tiang.

Perkembangan teknologi komputer yang cukup pesat menghasilkan software yang dapat digunakan untuk analisis dan memprediksi kapasitas pondasi tiang secara cepat dan baik. GRLWEAP merupakan program komputer yang dapat digunakan untuk menentukan kapasitas tiang berdasarkan hasil pengujian dinamik berupa simulasi pemancangan pondasi tiang dengan memasukkan parameter hammer, pondasi tiang, dan tanah. Output program berupa tegangan yang terjadi sepanjang tiang dan estimasi kapasitas aksial. Sementara itu untuk menganalisa kapasitas tiang secara aksial dan lateral digunakan program APILE Offshore dan LPILE. Hasil analisa dengan program dan data pengujian tiang di lapangan akan dibandingkan dengan besarnya beban yang bekerja pada masingmasing tiang dalam kondisi statik dan service. Oleh sebab itu, untuk menganalisa penyebab kegagalan tiang pancang 
yang terjadi pada konstruksi dermaga pada salah satu kawasan pulau di Indonesia dilakukan dengan program APILE Offshore, LPILE, dan GRLWEAP.

\section{METODOLOGI PENELITIAN}

\section{Studi Literatur}

Penelitian dimulai dengan mengumpulkan teori untuk analisis penyebab kegagalan tiang pancang pada konstruksi dermaga pada salah satu kawasan pulau di Indonesia berupa buku, jurnal, dan peraturan seperti API Recommended Practice 2GEO 2014 Geotechnical and Foundation Design Consideration dan SNI 8460:2017 tentang Persyaratan Perancangan Geoteknik.

\section{Hipotesis Penyebab Kegagalan Tiang Pancang}

Langkah selanjutnya melakukan hipotesis (pendugaan sementara) terhadap penyebab kegagalan pada tiang pancang konstruksi dermaga, antara lain:

- Letak pelabuhan yang berada sangat dekat dengan muara sungai sehingga pada saat musim banjir, debit sungai membawa muatan material yang cukup besar yang menyebabkan sedimentasi pada area dermaga. Adanya endapan sedimen pada dasar laut dermaga ini dapat menjadi beban tambahan bagi struktur dermaga, khususnya tiang pancang yang dapat mengakibatkan ketidakstabilan pada struktur dermaga.

- Selain potensi sedimentasi, terdapat potensi penggerusan (scouring) pada dermaga dan trestle. Apabila kembali terjadi curah hujan yang besar, dikhawatirkan akan terjadi perpindahan sedimen yang semakin tinggi.

- Semakin besar tiang bebas tiang pancang, maka potensi deformasi pada struktur dermaga dapat semakin besar.

- Pergeseran dermaga yang mengakibatkan dilatasi menjadi semakin renggang dapat disebabkan oleh gaya tekanan lateral akibat tumbukan kapal maupun banjir besar yang menimbulkan endapan sedimen sehingga mendorong dermaga bergerak maju. Selain itu, pergeseran dermaga dapat disebabkan oleh penurunan pada pondasi tiang.

\section{Pengumpulan dan Pengolahan Data}

Data-data yang dikumpulkan antara lain data tiang, data tanah dari hasil pengujian lapangan dan laboratorium, dan data hammer. Tiang yang digunakan adalah tiang pancang pipa baja (steel line pipe) open ended diameter 457,2 mm dan tebal 6,35 mm Grade A dengan kuat leleh 30000 psi (205 MPa) dan kuat tarik 48000 psi (330 MPa). Hammer yang digunakan tipe KOBE K 35. Data tanah pada bagian dermaga dan trestle adalah sebagai berikut.

Tabel 1. Parameter Tanah Bagian Dermaga

\begin{tabular}{|c|c|c|c|c|c|c|}
\hline Lapisan & Kedalaman (m) & Jenis tanah & $\mathbf{N}-\mathbf{S P T}$ & $\begin{array}{c}\text { Berat jenis, } \\
\gamma\left(\mathbf{k N} / \mathbf{m}^{3}\right)\end{array}$ & $\begin{array}{c}\text { Sudut geser, } \\
\phi \phi\left(^{0}\right)\end{array}$ & $\begin{array}{c}\text { Kepadatan } \\
\text { relatif, Dr }\end{array}$ \\
\hline 1 & $0-5$ & Pasir & 2 & 12,08 & 20,08 & 0 \\
\hline 2 & $5-10$ & Pasir & 9 & 14,95 & 23,00 & 0,1 \\
\hline 3 & $10-17$ & Pasir kelanauan & 12 & 17,04 & 24,00 & 0,15 \\
\hline 4 & $17-30$ & Pasir kelanauan & 18 & 17,02 & 24,71 & 0,35 \\
\hline 5 & $30-37$ & Pasir kelanauan & 25 & 17,80 & 26,20 & 0,4 \\
\hline 6 & $37-45$ & Pasir kelanauan & 28 & 17,50 & 26,00 & 0,59 \\
\hline 7 & $45-62$ & Pasir kelanauan & 38 & 17,50 & 27,33 & 0,7 \\
\hline
\end{tabular}

Tabel 2. Parameter Tanah Bagian Trestle

\begin{tabular}{|c|c|c|c|c|c|c|}
\hline Lapisan & Kedalaman (m) & Jenis tanah & $\mathbf{N}-\mathbf{S P T}$ & $\begin{array}{c}\text { Berat jenis, } \\
\gamma\left(\mathrm{kN} / \mathrm{m}^{3}\right)\end{array}$ & $\begin{array}{c}\text { Sudut geser, } \\
\phi\left(\left(^{0}\right)\right.\end{array}$ & $\begin{array}{l}\text { Kepadatan } \\
\text { relatif, Dr }\end{array}$ \\
\hline 1 & $0-5$ & Pasir & 3 & 12,88 & 21,00 & 0 \\
\hline 2 & $5-8$ & Pasir & 6 & 12,50 & 21,00 & 0,1 \\
\hline 3 & $8-25$ & Pasir kelanauan & 11 & 15,91 & 22,07 & 0,15 \\
\hline 4 & $25-30$ & Pasir kelanauan & 16 & 16,72 & 22,99 & 0,3 \\
\hline 5 & $30-35$ & Pasir kelanauan & 20 & 16,94 & 25,00 & 0,35 \\
\hline 6 & $35-45$ & Pasir kelanauan & 27 & 17,00 & 25,75 & 0,58 \\
\hline 7 & $45-62$ & Pasir kelanauan & 37 & 17,50 & 27,33 & 0,69 \\
\hline
\end{tabular}




\section{Analisis pada Program APILE Offshore}

Analisis pada program APILE Offshore dilakukan dengan memasukkan parameter tiang dan tanah. Setelah itu melakukan run analysis dan diperoleh kapasitas aksial tiang sepanjang kedalaman penetrasi tiang.

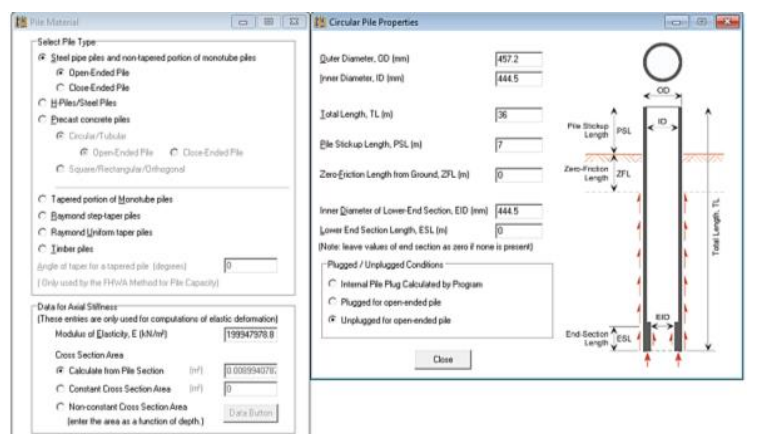

Gambar 1. Input Parameter Tiang pada Program APILE Offshore

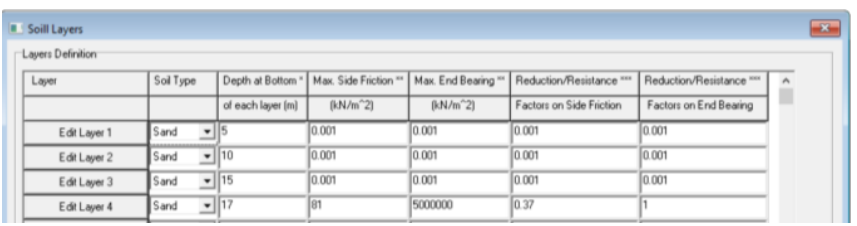

Gambar 2. Input Parameter Tanah pada Program APILE Offshore

\section{Analisis pada Program LPILE}

Analisis pada program LPILE dilakukan dengan memasukkan parameter tiang dan tanah. Untuk mengetahui kapasitas lateral tiang dilakukan dengan membatasi defleksi maksimum pada kepala tiang dengan input pembebanan opsi Deflection and Slope dimana besarnya defleksi pada kepala tiang dibatasi sebesar $1 / 2$ inch untuk gempa kuat dan $1 / 4$ inch untuk gempa nominal. Setelah itu melakukan run analysis dan diperoleh kapasitas lateral tiang.

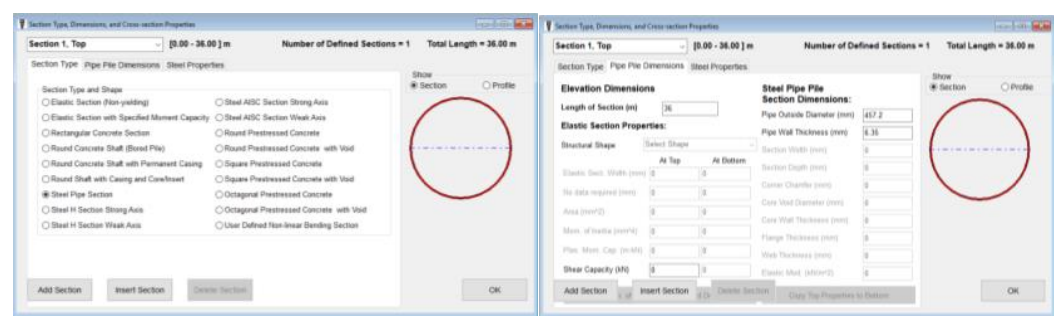

Gambar 3. Input Parameter Tiang pada Program LPILE

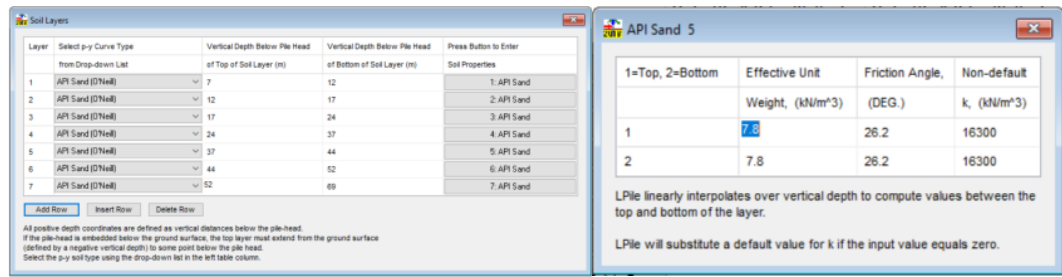

Gambar 4. Input Parameter Tanah pada Program LPILE

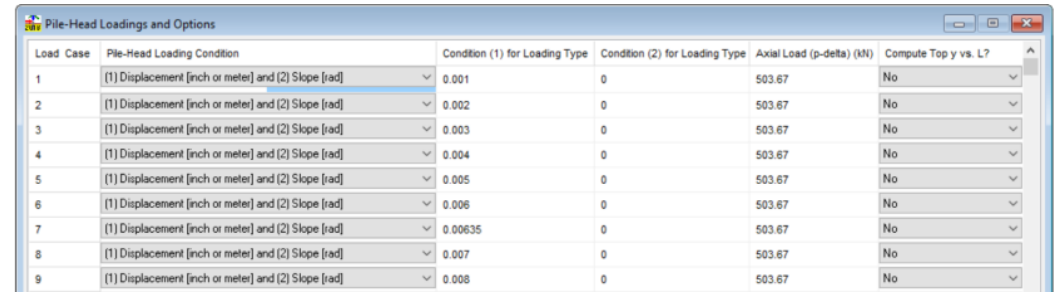

Gambar 5. Input Pembebanan pada Kepala Tiang Tipe Displacement and Slope 


\section{Analisis pada Program GRLWEAP}

Analisis pada program GRLWEAP dilakukan dengan memasukkan parameter hammer, tiang, dan tanah. Data parameter hammer berasal dari manufacturer. Tipe analisis yang digunakan adalah driveability dimana kapasitas tiang ditentukan nilainya berdasarkan gain/ loss factor pada shaft dan toe tiang. Faktor ini bertujuan untuk mengurangi atau meningkatkan nilai tahanan pada tiang. Hasil analisis berupa driveability graph yang menyatakan kapasitas tiang, jumlah pukulan, tegangan tarik dan tekan sepanjang tiang, energi yang ditansfer dari sistem pemancangan ke tiang, dan stroke terhadap panjang penetrasi tiang.

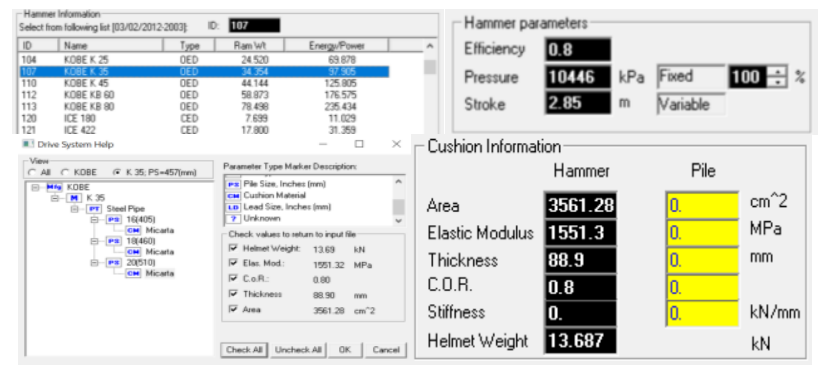

Gambar 6. Input Parameter Hammer dan Cushion KOBE K 35

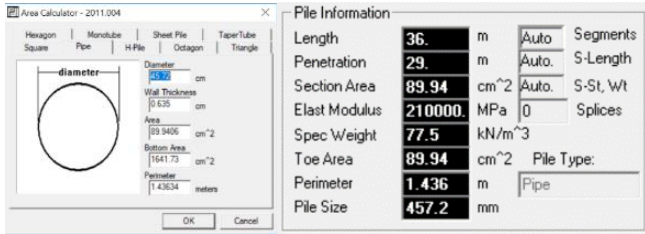

Gambar 7. Input Parameter Tiang pada Program GRLWEAP

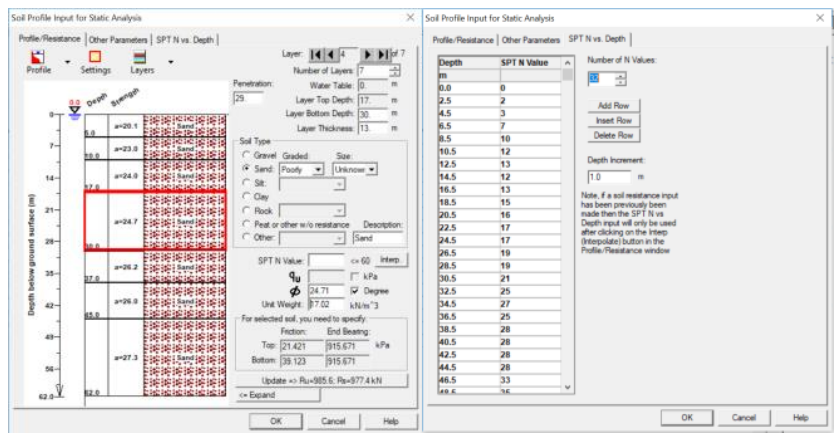

Gambar 8. Input Parameter Tiap Lapisan Tanah pada Program GRLWEAP

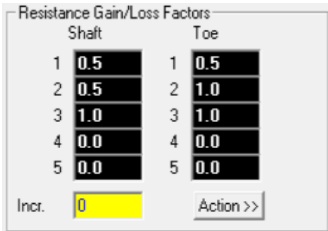

Gambar 9. Gain/loss Factor untuk Shaft dan Toe Resistance

Parameter tanah lainnya adalah quake dan damping. Quake merupakan deformasi elastis maksimum tanah yang terjadi. Nilai quake yang dianjurkan menurut program GRLWEAP adalah:

Tabel 3. Rekomendasi Nilai Quake Program GRLWEAP (Sumber: GRLWEAP 2010)

\begin{tabular}{|l||l|l||l|}
\hline & Soil Type & Pile Type or Size & Quake (in) Quake (mm) \\
\hline \hline Shaft Quake & All soil types & All Types & 0.102 .5 \\
\hline Toe Quake & All soil types, soft Rock & Non-displacement piles** i.e. driving unplugged & 0.102 .5 \\
\hline \hline & Very dense or hard soils & Displacement Piles*** of diameter or width D & D/120 D/120 \\
\hline & Soils which are not very dense or hard & Displacement Piles*** of diameter or width D & D/60 D/60 \\
\hline \hline & Hard Rock & All Types & 0.041 .0 \\
\hline
\end{tabular}




\section{HASIL DAN PEMBAHASAN}

\section{Perhitungan Daya Dukung Aksial Tiang Statik pada Dermaga dan Trestle}

Perhitungan daya dukung aksial tiang statik dilakukan dengan rumus Meyerhof. Analisis kapasitas tiang pipa baja open ended perlu mempertimbangkan efek plugging. Pertimbangan analisis yang akan digunakan adalah:

- Jika daya dukung friksi dalam tiang lebih besar daripada daya dukung ujung tiang kondisi close ended, maka tiang dianggap berperilaku seperti penampang close ended sehingga daya dukung ultimate adalah daya dukung friksi luar dan daya dukung tiang ujung close ended.

$$
\mathrm{Q}_{\text {side (inner) }}>\mathrm{Q}_{\text {Tip (closed ended) }}, \text { maka } \mathrm{Q}_{\mathrm{ult}}=\mathrm{Q}_{\text {side (outer) }}+\mathrm{Q}_{\text {Tip (closed ended) }}
$$

- Jika daya dukung friksi dalam lebih kecil dari daya dukung ujung tiang close ended, maka tiang dianggap berperilaku seperti penampang open ended sehingga daya dukung ultimat adalah daya dukung friksi luar dan friksi dalam.

$$
\mathrm{Q}_{\text {side (inner) }}<\mathrm{Q}_{\text {Tip (closed ended) }} \text {, maka } \mathrm{Q}_{\text {ult }}=\mathrm{Q}_{\text {side (outer) }}+\mathrm{Q}_{\text {side (inner) }}
$$

Syarat kondisi plugged pada tanah cohesionless berdasarkan API Recommended Practice 2GEO 2014 Appendix C:

$$
\operatorname{Di}<2(\operatorname{Dr}-0,3)
$$

Perhitungan daya dukung ujung dan selimut pondasi tiang pancang pipa baja dengan cara statik adalah:

$$
\begin{gathered}
\mathrm{Q}_{\text {tip }}=\mathrm{A}_{\text {tip }} \times \mathrm{q}_{\mathrm{t}}=\mathrm{A}_{\text {tip }} \times 4 . \mathrm{N} \\
\mathrm{Q}_{\text {side }}=\sum \mathrm{f}_{\mathrm{s}} \mathrm{l}_{\mathrm{i}} \cdot \mathrm{p}
\end{gathered}
$$

\begin{tabular}{|c|c|c|c|c|c|}
\hline $\begin{array}{l}\text { Lokasi } \\
\text { Tiang }\end{array}$ & $\begin{array}{c}\text { Panjang } \\
\text { Tiang, L (m) }\end{array}$ & $\begin{array}{c}\text { Panjang } \\
\text { freestanding }(\mathrm{m})\end{array}$ & Kondisi & Qu $(k N)$ & Qall (kN) \\
\hline \multirow{14}{*}{ Dermaga } & \multirow{9}{*}{36} & 6 & Unplugged & 708.27 & 283.31 \\
\hline & & 7 & Unplugged & 659.28 & 263.71 \\
\hline & & 8 & Unplugged & 610.28 & 244.11 \\
\hline & & 9 & Unplugged & 561.29 & 224.52 \\
\hline & & 10 & Unplugged & 512.29 & 204.92 \\
\hline & & 11 & Unplugged & 463.30 & 185.32 \\
\hline & & 12 & Unplugged & 414.30 & 165.72 \\
\hline & & 13 & Unplugged & 365.31 & 146.12 \\
\hline & & 14 & Unplugged & 316.31 & 126.53 \\
\hline & \multirow{5}{*}{48} & 10 & Unplugged & 1273.23 & 509.29 \\
\hline & & 11 & Unplugged & 1202.61 & 481.04 \\
\hline & & 12 & Unplugged & 1131.99 & 452.80 \\
\hline & & 13 & Unplugged & 1061.37 & 424.55 \\
\hline & & 14 & Unplugged & 990.75 & 396.30 \\
\hline \multirow{6}{*}{ Trestle } & \multirow{6}{*}{36} & 4 & Unplugged & 648.27 & 259.31 \\
\hline & & 5 & Unplugged & 594.76 & 237.91 \\
\hline & & 6 & Unplugged & 541.26 & 216.50 \\
\hline & & 7 & Unplugged & 504.15 & 201.66 \\
\hline & & 8 & Unplugged & 467.05 & 186.82 \\
\hline & & 9 & Unplugged & 429.94 & 171.98 \\
\hline
\end{tabular}

Kemudian perhitungan dilakukan pada semua tipe tiang pada dermaga dan trestle dengan panjang 36 meter dan 48 meter serta panjang tiang bebas $4 \mathrm{~m}-14 \mathrm{~m}$ yang dapat dilihat pada tabel berikut ini:

Tabel 4. Daya Dukung Tiang Pancang Statik Meyerhof 


\section{Analisis Daya Dukung Aksial dengan Program APILE Offshore}

Kapasitas aksial yang akan diperhitungkan adalah metode API. Output kapasitas berupa kapasitas selimut, kapasitas ujung, dan kapasitas total yang dapat dilihat pada tabel berikut.

Tabel 5. Daya Dukung Aksial dengan Program APILE Offshore

\begin{tabular}{|c|c|c|c|c|c|}
\hline $\begin{array}{l}\text { Lokasi } \\
\text { Tiang }\end{array}$ & $\begin{array}{c}\text { Panjang } \\
\text { Tiang, L (m) }\end{array}$ & $\begin{array}{c}\text { Panjang } \\
\text { freestanding }(\mathrm{m})\end{array}$ & $\mathbf{Q}_{\text {tip }}(\mathbf{k N})$ & $\mathbf{Q}_{\text {side }}(\mathbf{k N})$ & $\begin{array}{c}\text { Axial Capacity, } \\
\mathrm{Q}(\mathrm{kN})\end{array}$ \\
\hline \multirow{14}{*}{ Dermaga } & \multirow{9}{*}{36} & 6 & 39.2 & 275.8 & 315 \\
\hline & & 7 & 37.7 & 252 & 289.7 \\
\hline & & 8 & 35.8 & 221.7 & 257.5 \\
\hline & & 9 & 34.3 & 200 & 234.3 \\
\hline & & 10 & 32.9 & 179.1 & 212 \\
\hline & & 11 & 31.5 & 159.2 & 190.7 \\
\hline & & 12 & 29.5 & 134 & 163.5 \\
\hline & & 13 & 28.1 & 116.2 & 144.3 \\
\hline & & 14 & 26.6 & 99.2 & 125.9 \\
\hline & \multirow{5}{*}{48} & 10 & 59.3 & 542.3 & 601.6 \\
\hline & & 11 & 57.6 & 507.5 & 565 \\
\hline & & 12 & 55.8 & 473.5 & 529.3 \\
\hline & & 13 & 53.4 & 430 & 483.3 \\
\hline & & 14 & 51.6 & 398.6 & 450.1 \\
\hline \multirow{6}{*}{ Trestle } & \multirow{6}{*}{36} & 4 & 37.5 & 288.9 & 326.4 \\
\hline & & 5 & 36.1 & 265.8 & 301.8 \\
\hline & & 6 & 27.7 & 244.7 & 272.4 \\
\hline & & 7 & 26.6 & 225.6 & 252.3 \\
\hline & & 8 & 25.1 & 201.4 & 226.6 \\
\hline & & 9 & 24 & 184.2 & 208.2 \\
\hline
\end{tabular}

\section{Analisis Daya Dukung Aksial dengan Program GRLWEAP}

Hasil analisis berupa driveability graph sebagai berikut.

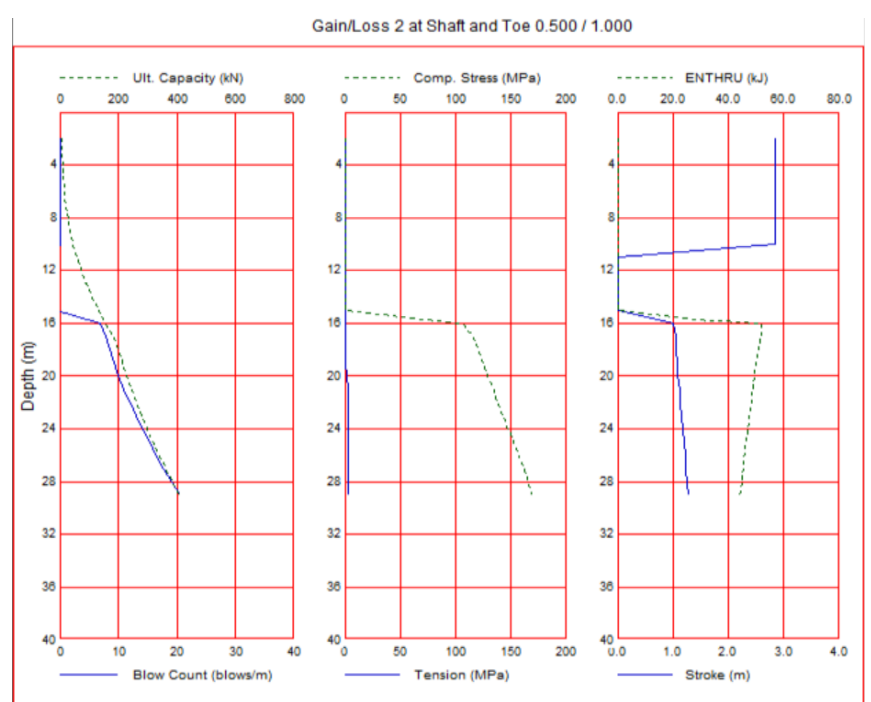

Gambar 10. Grafik Driveability pada Tiang Dermaga L = $36 \mathrm{~m}$ dan Panjang Freestanding $7 \mathrm{~m}$

Tegangan tarik dan tekan yang diijinkan untuk material tiang baja adalah:

$$
\sigma_{\mathrm{ijin}}=0,9 . \mathrm{f}_{\mathrm{y}}
$$

Dengan demikian, hasil analisis dengan program GRLWEAP adalah sebagai berikut: 
Jurnal Mitra Teknik Sipil

Vol. 1, No. 1, Agustus 2018: hlm 177-186

Tabel 6. Hasil Analisis Program GRLWEAP

\begin{tabular}{|c|c|c|c|c|c|c|}
\hline $\begin{array}{l}\text { Lokasi } \\
\text { Tiang }\end{array}$ & $\begin{array}{c}\text { Panjang } \\
\text { Tiang, L (m) }\end{array}$ & $\begin{array}{c}\text { Panjang } \\
\text { freestanding }(\mathbf{m})\end{array}$ & $\begin{array}{c}\text { Kapasitas } \\
\text { Tiang }(k N)\end{array}$ & $\begin{array}{c}\text { Tegangan } \\
\text { Tekan (MPa) }\end{array}$ & $\begin{array}{c}\text { Tegangan } \\
\text { Tarik (MPa) }\end{array}$ & $\begin{array}{c}\text { Cek Integritas } \\
\text { Tiang }\end{array}$ \\
\hline \multirow{14}{*}{ Dermaga } & \multirow{9}{*}{36} & 6 & 431.8 & 171.272 & -3.016 & $\mathrm{OK}$ \\
\hline & & 7 & 406.8 & 168.305 & -3.207 & OK \\
\hline & & 8 & 382.8 & 165.218 & -3.369 & OK \\
\hline & & 9 & 359.28 & 161.835 & -3.381 & OK \\
\hline & & 10 & 334.1 & 156.698 & -4.151 & OK \\
\hline & & 11 & 316.8 & 152.135 & -3.131 & OK \\
\hline & & 12 & 296.8 & 147.705 & -2.914 & OK \\
\hline & & 13 & 274.2 & 141.682 & -3.631 & OK \\
\hline & & 14 & 256.2 & 137.193 & -3.461 & OK \\
\hline & \multirow{5}{*}{48} & 10 & 672.4 & 180.135 & -7.838 & OK \\
\hline & & 11 & 637.4 & 178.708 & -5.113 & $\overline{\mathrm{OK}}$ \\
\hline & & 12 & 605.4 & 177.726 & -3.134 & OK \\
\hline & & 13 & 568.4 & 176.380 & -1.960 & OK \\
\hline & & 14 & 544.8 & 174.852 & -1.756 & OK \\
\hline \multirow{6}{*}{ Trestle } & \multirow{6}{*}{36} & 4 & 441.3 & 169.335 & -4.851 & OK \\
\hline & & 5 & 417.9 & 166.552 & -5.036 & OK \\
\hline & & 6 & 394.8 & 163.440 & -5.764 & OK \\
\hline & & 7 & 373.7 & 160.641 & -6.208 & OK \\
\hline & & 8 & 353.5 & 157.738 & -6.584 & OK \\
\hline & & 9 & 334.2 & 154.253 & -6.442 & $\mathrm{OK}$ \\
\hline
\end{tabular}

\section{Analisis Daya Dukung Lateral dengan Program LPILE}

Kapasitas lateral tiang ijin yang akan diperhitungkan berdasarkan pembatasan defleksi maksimum sebesar $1 / 2$ inch untuk gempa kuat dan 1/4 inch untuk gempa nominal. Kapasitas ijin lateral tiang dapat dilihat pada tabel berikut.

Tabel 7. Hasil Analisis Program LPILE

\begin{tabular}{|c|c|c|c|c|c|c|c|c|}
\hline \multirow{2}{*}{$\begin{array}{c}\text { Lokasi } \\
\text { Tiang }\end{array}$} & \multirow{2}{*}{$\begin{array}{c}\text { Panjang } \\
\text { Tiang, L } \\
\text { (m) }\end{array}$} & \multirow{2}{*}{$\begin{array}{c}\text { Panjang } \\
\text { freestanding } \\
\text { pile }(\mathbf{m})\end{array}$} & \multicolumn{2}{|c|}{$\mathbf{H}_{\text {all }}(\mathbf{k N})$} & \multicolumn{2}{|c|}{$\begin{array}{l}\text { Momen maksimum } \\
\qquad(\mathrm{kNm})\end{array}$} & \multicolumn{2}{|c|}{ Defleksi maksimum (m) } \\
\hline & & & $\begin{array}{c}\text { Defleksi } \\
1 / 4 "\end{array}$ & $\begin{array}{c}\text { Defleksi } \\
1 / 2 "\end{array}$ & Statik & Service & Statik & Service \\
\hline \multirow{14}{*}{ Dermaga } & \multirow{9}{*}{36} & 6 & 4.307 & 8.3199 & 122.75 & 182.58 & 0.0515 & 0.0865 \\
\hline & & 7 & 3.729 & 7.2219 & 139.71 & 207.98 & 0.072 & 0.13 \\
\hline & & 8 & 3.2196 & 6.3205 & 158.14 & $\left.-^{*}\right)$ & 0.098 & $-^{*)}$ \\
\hline & & 9 & 2.8135 & 5.4951 & 178.46 & $\left.-{ }^{*}\right)$ & 0.1335 & $\left.-{ }^{*}\right)$ \\
\hline & & 10 & 2.4561 & 4.8785 & 201.53 & $\left.-{ }^{*}\right)$ & 0.1845 & $\left.-{ }^{*}\right)$ \\
\hline & & 11 & 2.1774 & 4.286 & $-^{*)}$ & $\left.-{ }^{*}\right)$ & $\left.-^{*}\right)$ & $-{ }^{*)}$ \\
\hline & & 12 & 1.9228 & 3.8445 & $\left.-{ }^{*}\right)$ & $\left.-{ }^{*}\right)$ & $\left.-{ }^{*}\right)$ & $\left.-{ }^{*}\right)$ \\
\hline & & 13 & 1.723 & 3.4238 & $\left.-{ }^{*}\right)$ & $\left.-{ }^{*}\right)$ & $\left.-{ }^{*}\right)$ & $\left.-{ }^{*}\right)$ \\
\hline & & 14 & 1.5478 & 3.0837 & $\left.-{ }^{*}\right)$ & $\left.-{ }^{*}\right)$ & $\left.-{ }^{*}\right)$ & $\left.-{ }^{*}\right)$ \\
\hline & \multirow{5}{*}{48} & 10 & 2.4372 & 4.8192 & 202.37 & $\left.-{ }^{*}\right)$ & 0.1874 & $-{ }^{*)}$ \\
\hline & & 11 & 2.1562 & 4.2535 & $-^{*)}$ & $\left.-{ }^{*}\right)$ & $\left.-^{*}\right)$ & $\left.-{ }^{*}\right)$ \\
\hline & & 12 & 1.9174 & 3.7751 & $\left.-{ }^{*}\right)$ & $\left.-{ }^{*}\right)$ & $\left.-{ }^{*}\right)$ & $\left.-^{*}\right)$ \\
\hline & & 13 & 1.7116 & 3.3691 & $\left.-{ }^{*}\right)$ & $\left.-{ }^{*}\right)$ & $\left.-{ }^{*}\right)$ & $\left.-{ }^{*}\right)$ \\
\hline & & 14 & 1.5348 & 3.0338 & $-^{*)}$ & $\left.-{ }^{*}\right)$ & $\left.-^{*}\right)$ & $-^{*)}$ \\
\hline \multirow{6}{*}{ Trestle } & \multirow{6}{*}{36} & 4 & 8.3683 & 14.5861 & 87.15 & 128.41 & 0.0206 & 0.033 \\
\hline & & 5 & 5.8902 & 10.5423 & 101.51 & 149.55 & 0.031 & 0.0495 \\
\hline & & 6 & 4.404 & 8.5826 & 116.69 & 171.85 & 0.0448 & 0.0724 \\
\hline & & 7 & 3.7469 & 7.4085 & 132.97 & 195.73 & 0.0629 & 0.106 \\
\hline & & 8 & 3.2574 & 6.3905 & 150.61 & $\left.-^{*}\right)$ & 0.0862 & $\left.-^{*}\right)$ \\
\hline & & 9 & 2.82 & 5.6182 & 169.91 & $\left.-^{*}\right)$ & 0.117 & $\left.-^{*}\right)$ \\
\hline
\end{tabular}

Catatan: ${ }^{*}$ Akibat beban maksimum (kondisi statik dan service), defleksi yang terjadi melampaui batas defleksi ijin. Hal ini disebabkan karena tiang mengalami overloading. 


\section{Perbandingan Hasil Kapasitas Aksial}

Hasil analisis kapasitas aksial hasil perhitungan statik dengan rumus Meyerhof dibandingkan dengan hasil analisis dengan program, PDA test, dan kalendering terhadap beban dari struktur dapat dilihat pada tabel berikut.

Tabel 8. Perbandingan Daya Dukung Aksial Tiang Pancang Pipa Baja

\begin{tabular}{|c|c|c|c|c|c|c|c|c|c|c|}
\hline \multirow{2}{*}{$\begin{array}{c}\text { Lokasi } \\
\text { Tiang }\end{array}$} & \multirow{2}{*}{$\begin{array}{l}\text { Panjang } \\
\text { Tiang, L } \\
\quad(\mathrm{m})\end{array}$} & \multirow{2}{*}{$\begin{array}{c}\text { Panjang } \\
\text { freestanding } \\
\text { pile }(\mathbf{m})\end{array}$} & \multirow{2}{*}{$\begin{array}{c}\text { Lokasi } \\
\text { Tiang }\end{array}$} & \multicolumn{2}{|c|}{$\begin{array}{l}\text { Beban dari } \\
\text { Struktur }\end{array}$} & \multicolumn{5}{|c|}{ Kapasitas Ijin (kN) } \\
\hline & & & & Statik & Service & Meyerhoff & $\begin{array}{c}\text { APILE } \\
\text { Offshore }\end{array}$ & GRLWEAP & $\begin{array}{l}\text { PDA } \\
\text { Test }\end{array}$ & Kalendering \\
\hline \multirow{14}{*}{ Dermaga } & \multirow{9}{*}{36} & 6 & $\mathrm{C} 7$ & \multirow{7}{*}{$\begin{array}{c}\text { Tengah } \\
= \\
503,67 \\
\mathrm{kN}\end{array}$} & \multirow{7}{*}{$\begin{array}{c}\text { Tengah } \\
= \\
549,23 \\
\mathrm{kN}\end{array}$} & 283.31 & 315 & 431.8 & 499.14 & 1165.63 \\
\hline & & 7 & B7 & & & 263.71 & 289.7 & 406.8 & 466.57 & 1165.63 \\
\hline & & 8 & C9 & & & 244.11 & 257.5 & 382.8 & & 1163.87 \\
\hline & & 9 & C11 & & & 224.52 & 234.3 & 359.28 & & 1344.63 \\
\hline & & 10 & B17 & & & 204.92 & 212 & 334.1 & & 1016.08 \\
\hline & & 11 & $\mathrm{~B} 12$ & & & 185.32 & 190.7 & 316.8 & & 1210.96 \\
\hline & & 12 & $\mathrm{C} 13$ & & & 165.72 & 163.5 & 296.8 & & 1321.04 \\
\hline & & 13 & $\mathrm{C} 14$ & \multirow{7}{*}{$\begin{array}{c}\text { Ujung } \\
= \\
508,05 \\
\mathrm{kN}\end{array}$} & \multirow{7}{*}{$\begin{array}{c}\text { Ujung } \\
= \\
553,61 \\
\mathrm{kN}\end{array}$} & 146.12 & 144.3 & 274.2 & & 1486.17 \\
\hline & & 14 & $\mathrm{C} 16$ & & & 126.53 & 125.9 & 256.2 & & 1453.15 \\
\hline & \multirow{5}{*}{48} & 10 & $\mathrm{~B} 1$ & & & 509.29 & 601.6 & 672.4 & & 1219.29 \\
\hline & & 11 & A1 & & & 481.04 & 565 & 637.4 & & 1143.09 \\
\hline & & 12 & $\mathrm{C} 18$ & & & 452.80 & 529.3 & 605.4 & & 1075.85 \\
\hline & & 13 & B18 & & & 424.55 & 483.3 & 568.4 & & 1219.29 \\
\hline & & 14 & A18 & & & 396.30 & 450.1 & 544.8 & & 1306.39 \\
\hline \multirow{6}{*}{ Trestle } & \multirow{6}{*}{36} & 4 & $\mathrm{~A} 1$ & \multirow{6}{*}{$\begin{array}{c}512,61 \\
\mathrm{kN}\end{array}$} & \multirow{6}{*}{$\begin{array}{c}552,61 \\
\mathrm{kN}\end{array}$} & 259.31 & 326.4 & 441.3 & & \\
\hline & & 5 & $\mathrm{~A} 2$ & & & 237.91 & 301.8 & 417.9 & & \\
\hline & & 6 & A3 & & & 216.50 & 272.4 & 394.8 & & \\
\hline & & 7 & A6 & & & 201.66 & 252.3 & 373.7 & 501.14 & \\
\hline & & 8 & A8 & & & 186.82 & 226.6 & 353.5 & 493.43 & \\
\hline & & 9 & A11 & & & 171.98 & 208.2 & 334.2 & & \\
\hline
\end{tabular}
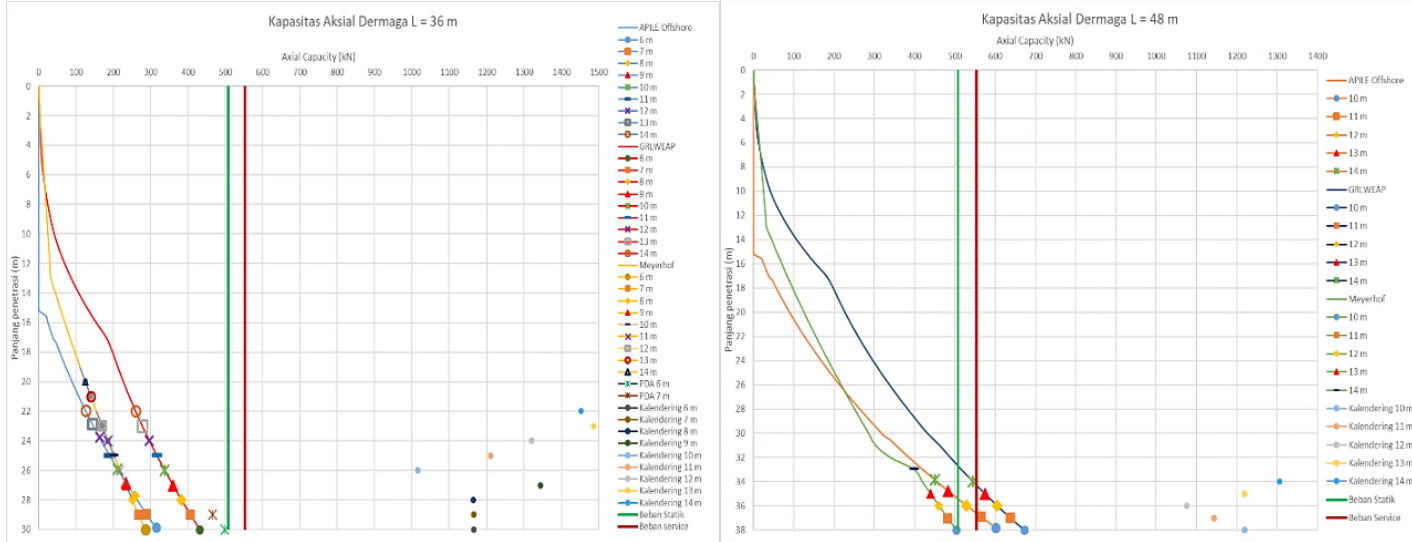

Gambar 11. Perbandingan Kapasitas Aksial Tiang Dermaga $\mathrm{L}=36 \mathrm{~m}$ dan $\mathrm{L}=48 \mathrm{~m}$

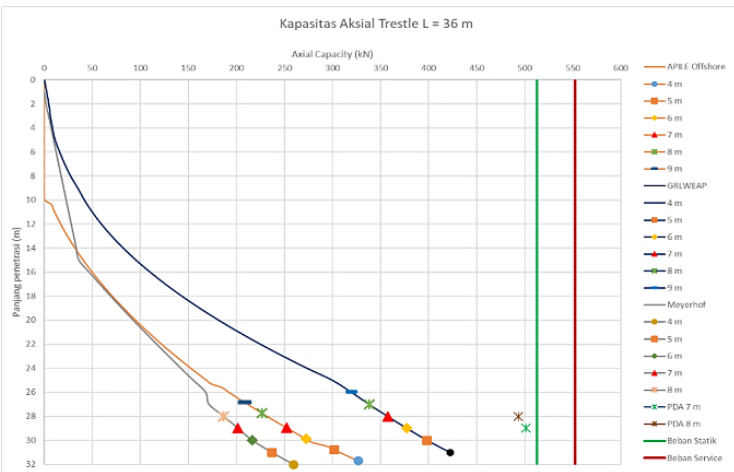

Gambar 12. Perbandingan Kapasitas Aksial Tiang Trestle L $=36 \mathrm{~m}$

Maka berdasarkan perbandingan kapasitas dengan beban aksial yang bekerja pada kondisi statik dan service, tiang mengalami kegagalan karena beban yang bekerja melebihi kapasitas aksial tiang. 


\section{Perbandingan Hasil Kapasitas Lateral}

Hasil analisis kapasitas lateral hasil analisis dengan program LPILE terhadap beban dari struktur dapat dilihat pada tabel berikut.

Tabel 9. Perbandingan Daya Dukung Lateral Tiang Pancang Pipa Baja

\begin{tabular}{|c|c|c|c|c|c|c|c|c|}
\hline \multirow{2}{*}{$\begin{array}{c}\text { Lokasi } \\
\text { Tiang }\end{array}$} & \multirow{2}{*}{$\begin{array}{c}\text { Panjang } \\
\text { Tiang, L (m) }\end{array}$} & \multirow{2}{*}{$\begin{array}{c}\text { Panjang freestanding } \\
\text { pile }(\mathbf{m})\end{array}$} & \multicolumn{2}{|c|}{$\begin{array}{c}\text { Beban dari } \\
\text { Struktur }(k N)\end{array}$} & \multicolumn{2}{|c|}{$\mathbf{H}_{\text {all }}(\mathbf{k N})$} & \multicolumn{2}{|c|}{$\begin{array}{c}\text { Momen maksimum } \\
(\mathbf{k N m})\end{array}$} \\
\hline & & & Statik & Service & Defleksi 1/4" & Defleksi 1/2" & Statik & Service \\
\hline \multirow{14}{*}{ Dermaga } & \multirow{9}{*}{36} & 6 & \multirow{20}{*}{21.1} & \multirow{20}{*}{29.5} & 4.307 & 8.3199 & 122.75 & 182.58 \\
\hline & & 7 & & & 3.729 & 7.2219 & 139.71 & 207.98 \\
\hline & & 8 & & & 3.2196 & 6.3205 & 158.14 & $\left.-{ }^{*}\right)$ \\
\hline & & 9 & & & 2.8135 & 5.4951 & 178.46 & $\left.-^{*}\right)$ \\
\hline & & 10 & & & 2.4561 & 4.8785 & 201.53 & $\left.-^{*}\right)$ \\
\hline & & 11 & & & 2.1774 & 4.286 & $\left.-^{*}\right)$ & $\left.-^{*}\right)$ \\
\hline & & 12 & & & 1.9228 & 3.8445 & $\left.-{ }^{*}\right)$ & $\left.-^{*}\right)$ \\
\hline & & 13 & & & 1.723 & 3.4238 & $\left.-^{*}\right)$ & $\left.-^{*}\right)$ \\
\hline & & 14 & & & 1.5478 & 3.0837 & $\left.-{ }^{*}\right)$ & $\left.-^{*}\right)$ \\
\hline & \multirow{5}{*}{48} & 10 & & & 2.4372 & 4.8192 & 202.37 & $\left.-^{*}\right)$ \\
\hline & & 11 & & & 2.1562 & 4.2535 & $\left.-{ }^{*}\right)$ & $\left.-^{*}\right)$ \\
\hline & & 12 & & & 1.9174 & 3.7751 & $\left.-{ }^{*}\right)$ & $\left.-{ }^{*}\right)$ \\
\hline & & 13 & & & 1.7116 & 3.3691 & $\left.-^{*}\right)$ & $\left.-^{*}\right)$ \\
\hline & & 14 & & & 1.5348 & 3.0338 & $\left.-^{*}\right)$ & $\left.-{ }^{*}\right)$ \\
\hline \multirow{6}{*}{ Trestle } & \multirow{6}{*}{36} & 4 & & & 8.3683 & 14.5861 & 87.15 & 128.41 \\
\hline & & 5 & & & 5.8902 & 10.5423 & 101.51 & 149.55 \\
\hline & & 6 & & & 4.404 & 8.5826 & 116.69 & 171.85 \\
\hline & & 7 & & & 3.7469 & 7.4085 & 132.97 & 195.73 \\
\hline & & 8 & & & 3.2574 & 6.3905 & 150.61 & $\left.-{ }^{*}\right)$ \\
\hline & & 9 & & & 2.82 & 5.6182 & 169.91 & $\left.-^{*}\right)$ \\
\hline
\end{tabular}
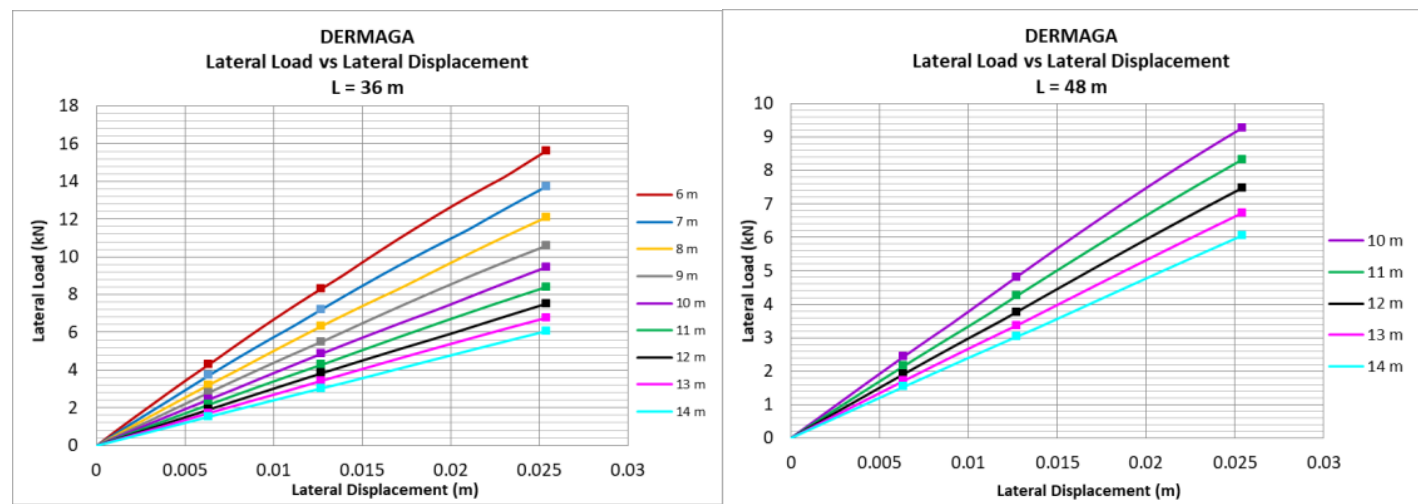

Gambar 13. Perbandingan Kapasitas Lateral Tiang Dermaga L $=36 \mathrm{~m}$ dan $\mathrm{L}=48 \mathrm{~m}$

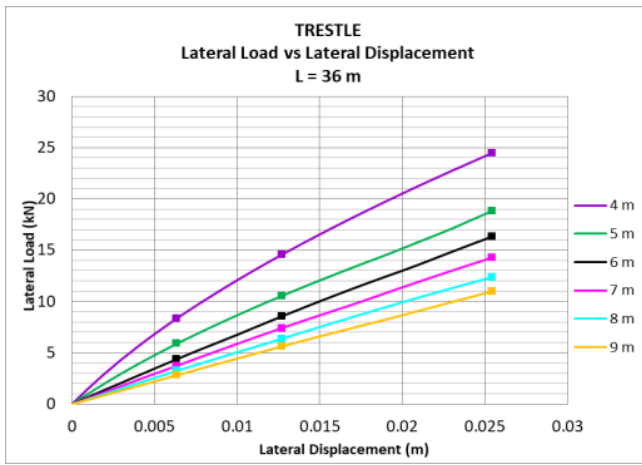

Gambar 14. Perbandingan Kapasitas Lateral Tiang Trestle $\mathrm{L}=36 \mathrm{~m}$

Maka berdasarkan perbandingan kapasitas hasil analisis dengan program LPILE dengan beban lateral yang bekerja pada kondisi statik dan service, tiang mengalami kegagalan karena beban yang bekerja melebihi kapasitas tiang. 


\section{KESIMPULAN}

1. Hasil analisis daya dukung aksial dengan perhitungan secara manual, program APILE Offshore, dan program GRLWEAP tidak memenuhi syarat kestabilan struktur karena beban vertikal baik kondisi statik maupun service yang bekerja pada masing-masing tiang melampaui kapasitas daya dukung ijin aksial.

2. Hasil analisis daya dukung lateral dengan program LPILE menunjukkan tiang tidak dapat menahan beban lateral secara statik dan service yang melampaui kapasitas tiang lateral.

3. Berdasarkan analisis dengan program GRLWEAP, tegangan tekan pada ujung tiang hampir mendekati batas tegangan tekan ijin sebesar 184,5 MPa namun belum mengalami leleh dan rusak saat pemancangan. Sedangkan tegangan tarik tiang dalam kondisi aman.

4. Kegagalan yang terjadi pada pondasi tiang pipa baja konstruksi dermaga disebabkan karena kesalahan dalam mendesain struktur dermaga dan trestle, yaitu salah dalam menentukan posisi pelabuhan yang terletak di muara yang membawa endapan sehingga menurunkan kapasitas pondasi, ujung tiang yang tidak bersandar pada tanah keras, tidak mempertimbangkan beban siklik dan efek scouring.

5. Semakin besar panjang tiang bebas (freestanding) tiang pancang, maka potensi deformasi pada struktur dermaga dapat semakin besar. Hal ini terbukti oleh semakin menurunnya kapasitas daya dukung baik aksial maupun lateral dengan semakin berkurangnya panjang penetrasi ke dalam tanah, karena tanah yang menyumbangkan tahanan selimut tiang berkurang.

\section{DAFTAR PUSTAKA}

American Petroleum Institute. (2014). Geotechnical and Foundation Design Considerations. Washington, DC: API. APILE 2015 - User's Manual. (2015). A Program for the Sudy of Driven Piles under Axial Loads. Texas: Ensoft, Inc.

Badan Standarisasi Nasional. (2017). SNI 8460:2017 Persyaratan Perancangan Geoteknik. Jakarta: BSN.

Bowles, J.E. (1991). Analisa dan Desain Pondasi Edisi keempat Jilid 1. Jakarta: Erlangga.

Bowles, J.E. (1991). Sifat-sifat Fisis dan Geoteknis Tanah (Mekanika Tanah). Jakarta: Erlangga.

Bowles, J.E. (1997). Foundation Analysis and Design 5th Edition. Singapore: McGraw - Hill Book Co.

Chamani, Mohammad R. Pier Scour. chamani.iut.ac.ir.

Coduto, Donald P. (2016). Foundation Design Principles and Practices 3rd Edition. California: Pearson.

Das, Braja M. (1993). Mekanika Tanah (Prinsip-prinsip Rekayasa Geoteknis) Jilid 2. Jakarta: Erlangga.

Dean, E.T.R. (2010). Offshore Geotechnical Engineering Principles and Practice. Great Britain: Thomas Telford.

Dictionary of Construction. Timber Pile. http://www.dictionaryofconstruction.com/definition/timber-pile.

Direktorat Pelabuhan dan Pengerukan Direktorat Jenderal Perhubungan Laut Kementrian Perhubungan. (2014). Detail Engineering Desain (DED) Pelabuhan Tahun Anggaran 2014. Bandung: Marga Nusantara Persada.

Dutch Foundation. Pile Testing. http://dfdubai.com/quality/pile-testing-2/.

Fundamentals of Environmental Measurements. https://www.fondriest.com/environmentalmeasurements/parameters/hydro-logy/sediment-transport-deposition/.

Ghazvinei, Pezhman, T. Scour Hazard Assessment and Bridge Abutment Instability Analysis. www.researchgate.net.

Hunt, Roy E. (2005). Geotechnical Engineering Investigation Handbook 2nd Edition. Broken Sound Parkway NW: Taylor \& Francis Group.

Introduction to Deep Foundations. http://slideplayer.com/slide/5730387/.

Kementrian Perhubungan Direktorat Jenderal Perhubungan Laut Kantor Unit Penyelenggara Pelabuhan (KUPP) Laut Kolaka. (2016). Laporan Pemancangan Dermaga. Sulawesi: KUPP.

LPILE 2018 - User's Manual. (2018). A Program to Analyze Deep Foundations Under Lateral Loading. Texas: Ensoft, Inc.

Masjedi, A. Reduction of Local Scour at a Bridge Pier using Collar in a 180 Degree Flume Bend. 2010. https://scialert.net/fulltext/?doi=jas.2010.124.131.

Mello, De. 1971. The Standard Penetration Test. 4th Panamerican Conference on Soil Mechanics and Foundation Engineering, San Juan (Puerto Rico). Vol. I. (Juni 1971): 1 - 86.

Pile Driving Analysis - Driven Piles. www.abuildersengineer.com.

Pile Driving Analyzer (PDA). http://www.earthproducts.in/pile-driving-analyzer-pda/.

Pile Dynamic, Inc. GRLWEAP 2010 help (http://www.pile.com/grlweap).

Randolph, Mark dan S. Gouvenec. (2011). Offshore Geotechnical Engineering. Oxon: Spon Press.

Terzaghi, Karl. (1967). Soil Mechanics in Engineering Practice. Singapore: Wiley.

Universitas Katolik Parahyangan. (2017). Manual Pondasi Tiang Edisi 5. Bandung: Universitas Katolik Parahyangan. 